\title{
NEW APPROACHES IN TEACHING ENGLISH TO STUDENTS OF AUTOMOBILE SPECIALTIES
}

\author{
Ponikarovska S. V. ${ }^{1}$ \\ ${ }^{1}$ Kharkiv National Automobile and Highway University
}

\begin{abstract}
Problem. New approaches in teaching foreign language, especially English as the language of international communication and the most common language in the internet space are the issue of many discussions and researches. Computers and telecommunications that are reshaping higher education, alter the daily operations and expand the missions and opportunities of universities, become the integral part of the teaching process. The students of engineering higher schools, especially future automobile engineers because they are at the cutting edge of modern industry, and, consequently, must be aware of new developments and be able to cooperate with foreign partners, require the combination of traditional and computer-assisted cooperative language learning which provides a space in which the facilitation of learning can take place. However, application of new technologies must be an assisting instrument, but not a self-inclusive tool. The task of a teacher is to be an integral part of the process, not an operator of the computer. Cultivation of students' capacity of thinking should be the major objective in teaching today. Goal. The goal of the article is proving that the education sector is no exception in our fast developing society. The nature of its target audience mostly young and highly connected-means that the sector must adapt to the new requirements, which means computer literacy and friendly atmosphere with the main task of facilitating learning. Methodology. Methods of analysis, research and development of new solution were used. Results. In the result of the analysis it was proven that new technologies together with new attitude bring a desired result in teaching foreign language in today's reality. Originality. Suggestions for using new technologies in the classroom as well as the ways to maintain working atmosphere with friendly communication are made, including the rapport among students themselves. Practical Value. The practical value of the work can be the ideas for improving development of the lesson, using gadgets for combination of individual work and consequent communication, prevention for a teacher from becoming just an assistant of technologies in the process of teaching.
\end{abstract}

Key words: atmosphere; communication; technology; knowledge; learning; interactive.

\section{Introduction}

Understanding of the fact that education is one of the main factors of civilizational and economic development of the state urges us today to strategically solve the tasks and provide system reformation of the national higher school, its adequate modernization and integration in the European economy, culture and information sphere. Modernization includes new technologies as an integral part of the progress and new approaches to developing the right atmosphere at the classes. Higher schools have always been quick to adopt new technologies. Throughout its history, higher education has experimented with technological advances. The $21^{\text {st }}$ century has shown increased use of technology-dependent resources in the classrooms and in the independent work. Technology has the potential to revolutionize the traditional teaching and learning process. It can eliminate the barriers of space and time and dramatically expand possibilities of lifelong learning. Fundamentally, modern technologies have the ability to change the conception of higher education. It is no longer only a physical place with classrooms. As they say, the standard image of a college or a university as a collection of "ivy-covered buildings" may need to be revised for the first time since the founding of Harvard in 1636. Yet, this can be a case of some very near future, but right now computers and telecommunications are the principal technologies reshaping higher education, and it is the absolute truth. They alter the daily operations and expand the missions and opportunities of colleges and universities. Together with new attitude and creating a friendly atmosphere of mutual understanding and friendly communication this can bring a desired result in teaching foreign language in today's reality.

\section{Analysis of Publications}

The essence of the process of introducing innovations in technologies and methods of education is the subject of the research of both foreign 
and Ukrainian scientists. Such researchers as A. Aleksiuk, I. Dobroskok, V. Illin, V. Kotsura, V. Kremen, S. Nikitchina, and others look into theoretical, scientific and practical problems of innovation paradigm in higher school, various progressive forms and technologies of education, experience and perspectives of their implementation in educational practice [2]. They connect innovations in education with necessity to improve the traditional teaching process and transformation of the existing process, i. e. radical changes. Other researchers, like O. Abdalova, V. Dokuchaieva, I. Halytsia, O. Halytsia, O. Vasylenko correlate the new in educational process with such features as useful, progressive, positive, modern, advanced [1, 3]. As the world new trend is the online courses and media-education, the authors emphasize that introduction of new technologies and mastering them require definite internal readiness for serious changes of both teachers and students of higher education.

\section{Purpose and Tasks}

The advance of globalization that is destroying, or at least lowering international barriers, competition among higher educational institutions contributes to "arms race" in technology that requires adoption of new technological innovations as soon as they become available. The alternative is falling behind other schools whose task is to recruit the students that could have become yours. This process can be painful for many reasons, not the smallest of them being material resources, shortage of space, cost of technological applications and software. The purpose of this work is to try to determine characteristic features of forms, methods and means of innovation education, consider the specific character of their use in interactive media of engineering higher schools of Ukraine. The major emphasis is made on training the students of automobile specialties.

\section{Technologies in teaching English to students of automobile specialties}

The list of professions where the specialists cannot do without English, among others, like programmers, journalists, managers of big companies, project managers, marketers, lawyers, web-designers, includes engineers of different specialties. The jokes about engineers belong to $90-$ s, they are history now. Today an engineer is a profession in demand, and one of the rare that is required abroad. That is exactly the reason why engineer needs English not less than some scien- tist or a diplomat. Even if an employer is not currently connected with some foreign partners, he prefers to hire an engineer with a decent knowledge of English. Firstly, this knowledge speaks about the flexibility of a person and their capabilities to study, and secondly, life develops and the possibilities of the company as well as of the individuals become wider. The profession of specialist in automobile production is one of the most required. If we speak about the connection of automobile area and English, we should remember several issues. Only some of them being the following: terminology - mostly English, the founders - English-speaking countries, the new technologies and material to find on the internet in English. No doubt thus, without English you cannot be at the cutting edge of the industry.

One of the most desired skill apart from knowledge now for the future automobile engineer is the skill of presentation. It is integral in the course of teaching ESP to future engineers, for example. As international relations become exceedingly wider, the graduates, working in their specialty, have the possibility or even a duty to visit conferences and other events on professional interests and sometimes make presentations there. Today presentations vary not only in topics and content, but in the ways of interaction of the speaker with the audience. The types are many: classic speeches through internet using video and audio with the speaker practically absent; group presentations in the form of a press conference or a master class or a round table.

So, the issue for the modern specialist in automobiles is not why to study English, but how to do it in current situation. The situation is as follows - variety of online possibilities, availability of electronic textbooks, wide usage of English terminology in modern engineering language, affordability of computers, gadgets and applications, the borders open for common people.

Technology disrupts almost every area of our lives, causing shifts across all segments of our society. The education sector is no exception. In fact, the nature of its target audience - mostly young and highly connected - means that the sector must adapt to accommodate their expectations. Most students have grown up "online", and they expect the same level of technology in their learning environments [4].

Educational technology today is beneficial for teaching process in many ways. Only traditional teaching is not efficient any more. Teachers must be equipped with complete manual having unlimited source of exercises and activi- 
ties for all levels, students must be much more involved and active. Here technology helps too as it is very motivating and stimulating for students. They like using devices in the classroom and outside, they can practice a language through numerous features like voice recognition or interactive exercises. It is great when they can easily switch between individual work and communication (work with earphones and smartphones when watching videos switching to subsequent discussion, the practice which we often use at the practical classes in groups of electronic automobile students). Students use different apps enriching their vocabulary profoundly, they are interested to the extent that they can even open the educational apps in transport or waiting for some event.

Managing and monitoring student progress become much easier and more comfortable with students' groups in messengers and e-mails. In the classroom sharing and debating becomes more "nurtured" with audio and video, a teacher just standing at the blackboard and explaining something is a history now, it happens only when a necessity arises.

In addition, maybe, one of the most important feature in learning with technologies is promoting individual work, when students become more creative and participative. They prepare some basis outside the classroom, engaging all the possible content online and share it in the classroom or even online. In my practice, one automobile student, for example, got so interested both in the specialty and in English that made a course of lectures and uploaded it on the You Tube. Moreover, it gathers many likes! They want to demonstrate what they have learned and use the language not just for the language's sake, but to communicate some interesting information in their specialty or some other area of life they are interested in.

The internet can offer automobile students abundant information, more plentiful than textbooks, and help them get true-to-life language material, vivid cultural background and rich content, which are much more natural and closer to life. They can not only improve their listening and reading skills, but also learn the western culture straight from the source. They become equipped with firsthand knowledge and can share it with their friends through discussion and communication, they can make new friends in social networks and become live friends with them later which happens with increasing frequency.

Teaching using multimedia creates a context of teaching. It helps make the class lively and interesting. Multimedia has its features such as visibility and audibility of the native speakers. All this nurtures students' interest in learning and, which is also important, enhances teachers' interest in teaching. Thus, through multimedia and network technology we can offer students not only rich sources of authentic learning materials, but also an attractive and friendly interface, vivid pictures and pleasant sounds, which, largely, overcomes the lack of authentic language environment and arouses students' interest in learning language [7].

But the challenge arises when educators realize that the technology can become an expensive toy without the right infrastructure, strategy or a learning plan. Application of multimedia technology is an assisting instrument to achieve the effect, while, if totally dependent on multimedia devices during teaching, the teacher can be turned into a slave to multimedia without any reason and any sensible effect. There are teachers who use technology very actively but do not handle it properly. Usually they just duplicate the textual material to the screen so the result is the students staring on the screen, no eye contact with the teacher, no actual use and no result whatsoever. Any technologies and approaches prove useful only if they have a positive effect.

Besides, some things have managed to stay the same as "before the technologies". For example, students and teachers of foreign language have not abandoned analog materials, and we are not going to do that soon. We continue to use papers and notebooks (though color and comfortable for use and interesting ones) to capture and visualize thought processes, and we will continue to need spaces and classrooms to support the parallel use of analog materials and digital tools for live communication. Oral explanation, teacher's interpretation of some difficult phenomena face-to-face to a student cannot be replaced by multimedia, the teacher's personality, live communication, blackboard with instant rewriting, crossing, checking and correcting, laugh, touch, encouragement - all these are still indispensable.

Here we face the new wave in optimization of language learning, which emphasizes that no technology can compensate the will, because emotions are the major psychological phenomena influencing the character of learning activity. The long experience of work shows that teaching English is more effective and productive when the positive mood prevails in the class, when the activity brings satisfaction, when some efforts are needed in case of a challenge of a 
difficult task or a serious problem of discussion. Students' emotions are closely connected with motives and express the possibility of realization of the tasks and aims that were set. Emotions can inspire students to learn and help this inspiration stay. The model of successful activity at the class includes deep immersion in different activities, awareness of the tasks and goals of study, absence of worry and anxiety in the process, positive emotions, commitment, attention, diligence and persistence.

Along with the emotions that stimulate the personality's activity and urge them to act, other emotions can arise, that cause the student to feel uncomfortable and passive. It is interesting though, that such strong negative emotions as anger and insult can also sometimes trigger their activity aiming to prove themselves.

Emotions do not depend on the specialty, and future automobilists face the same challenges as the young people studying any other area of science and industry. Psychologists believe that positive emotions not only create a special atmosphere in the classes, they also increase productivity of cognitive process such as thinking and memorizing, promote creativity in solving problems and fulfilling the tasks, i.e. they enhance learning. In addition, as in any other activity emotions come forward as primary before the real motives.

Both psychologists and pedagogues underline the role of positive motivation for study. At the same time it was proved, that high positive motivation can play a role of a compensating factor in case of "not good enough" capabilities of a student. The interesting fact is that this factor does not work the other way - no high level of student's knowledge and capabilities can compensate the absence of motive and consequently, cannot make a student successful.

Besides, when we speak about new approach to teaching, it would be great to remember that in most universities of the world students can choose the teacher whose classes they can attend. Of course, it concerns mostly the lecturers, when the students can choose the professor even from the other university because they consider him or her the best in their area. Therefore, the question arises if our students had a choice whom they would choose. The idea that they would choose the teacher who gives the best marks and is not strict belongs to the history. Only some students think this way, the majority prefer the teachers from whom they can get real knowledge. However, they all want the teacher to possess some other qualities, too. So, what makes a good teacher of English? Especially of English, as language exposure is still not much available outside the classroom, the role of English teacher is apparently significant. It has become a central issue for discussion at different levels and at several international conferences. The materials of some of them give us the general idea of the area of discussion. According to Park and Lee [8] the characteristics of effective English language teacher consists of three different categories, namely: subject matter knowledge, pedagogical knowledge, and socialaffective skills. Dincer, Goksu, Takkac and Yazici [6] add the fourth category - personality characteristics. Considering the issues under consideration in the article, we would also include technology literacy.

The first, socio-affective, refers to teachers' ability to have good relationship with students, to be enthusiastic, positive and creative for teaching, and to bring free-stress classroom. For pedagogical knowledge, teachers have the ability to organize and explain the course and to guide students with informative feedbacks. The third feature, subject-matter knowledge, means that the effective language teacher should know and master the subject to teach. As personal characteristics, the English teacher is effective when he/she has good personality. It demonstrates that the teacher should be someone who is patient, respectful, tolerant, kind, sensible, friendly, humorous, enthusiastic, and has other positive traits. Some researchers like Brown [5] add self-subordination and cultural adaptability to the list. They also underline that a good teacher should also know how to build a good rapport among students, which is very important when learning language, and manage the classroom and handle students' behavior.

From the students' part pedagogical knowledge is the most important in the good English language teacher. According to students' perception, the best teacher is the one who:

- prepares the lesson well;

- follows syllabus tightly;

- uses particular methods and technique in teaching;

- manages the class time well;

- assigns homework (though it may seem that this point of view is odd for the students);

-integrates group activities to the class;

- is up-to-date with technologies;

- teaches how to use English outside the classroom;

- teaches English adapted to students' profi- 
ciency level;

- maintains good classroom atmosphere using authority, if necessary;

- assesses what the students have learnt reasonably;

- provides opportunities to use English through meaningful tasks and activities;

- provides activities that arouse students' interest in learning English.

Besides, students list some traits as the qualities of effective English teacher, such as being helpful, friendly, humorous, fair, polite, respectful, flexible, attentive and open to criticism. The way the teacher behaves is considered significant not less than his knowledge. These are the socio-affective and personality issues highly perceived by students. The best teacher:

- is helpful in and outside the classroom;

- is available for students;

- alleviate students' anxiety in the English class;

- listens to the students' opinions and let them express themselves;

- helps students to develop self-confidence in order to learn English well;

- is friendly to students;

- has a good sense of humor;

- does not discriminate between students, treats them fairly;

- arouse students' motivation for learning English;

- shows interest in students (remembers their name, for example);

- is neat and tidy;

- pays attention to the personal needs of students;

- is polite; respects the personality of students;

- is disciplined and punctual;

- is flexible;

- is attentive to the class;

- does not lose temper and does not get angry.

Concisely, effective teachers master the subject matter well, know how to deliver it to the best advantage, and are good, respectful, and interesting figures for students.

\section{Conclusion}

From what was said above the following conclusions can be made. When we speak of new approaches in teaching English to the students of engineering higher schools, especially future automobile engineers as those standing at the cutting edge of modern industry and, conse- quently, those who must be aware of new developments and must be able to cooperate with foreign partners, we can summarize that the purpose of both the traditional and computerassisted cooperative language learning is to provide a space in which the facilitation of learning can take place. One of the ultimate goals of multumedia language teaching is to promote students' motivation and learning interest, which can be a practical way to get them involved in language learning. When teaching English is optimized by multimedia, students are more motivated to communicate with each other, they dive into the atmosphere of foreign language and culture, in authentic video and audio media. But application of new technologies must be an assisting instrument, not an independent tool. The task of a teacher is to be an integral part of the process, not an operator of the computer. The main idea of a new approach in teaching English is equipment of students with a firsthand knowledge of language and culture, giving them the instrument and possibilities of presentation, communication, acquiring new information. Cultivation of students' capacity of thinking should be the major objective in teaching today.

\section{Література}

1. Абдалова О. И. Исакова О. Ю. Использование технологий электронного обучения в учебном процессе. Дистанц. и виртуал. обучение. 2014. № 12. C. 50-55.

2. Саух П. Ю. та ін. Інновації у вищій освіті: проблеми, досвід, перспективи: монографія. ред. П. Ю. Саух. Житомир: Вид-во ЖДУ ім. I. Франка, 2011. 443 с.

3. Фатхутдінова О. В. Впровадження нових технологій в процесі підготовки спеціалістів правознавства. Гуманіт. вісн. Запоріз. держ. інж. акад. 2012. Вип. 48. С. 35-39.

1. Beatty K. Mobile language learning: the world in our hands. Anaheim University, USA. 2015 №17 URL: www.anaheim.edu/schools-and-institutes/ graduate-school-of-education/diplomaintesol/243-about/faculty-and-staff/tesolfaculty/886-ken-beatty-phd-ken-beatty-phd (дата звернення 10.07.2019)

4. Brown H. D. Teaching by Principles: An Interactive Approach to Language Pedagogy. New York: Pearson Education. 2007. 3d edition. 569 p.

5. Dincer A., Goksu A., Takkac A., Yazici M. Common Characteristics of an Effective English. The International Journal of Educational Researchers, 2013. No. 4(3). P. 1-8.

6. Frank V. M., Freynik S., Richardson D. L. Technologies for foreign language learning: a review of technology types and their effectiveness. Center for Advanced Study of Language, University of Maryland, College Park, MD. 2014. №1. P. 
27.

7. Park G.-P., Lee H.-W. The characteristics of effective English teachers as perceived by high school teachers and students in Korea. Asia Pacific Education Review, 2006. No. 7(2), 236-248 p.

\section{References}

1. Abdalova O. I., Isakova O. Yu. (2014) Ispolzovaniie texnologyy elektronnogo obucheniia $\mathrm{v}$ uchebnom processe [Using electronic technologies in teaching process]. Distancz. i virtual. obucheniie. 12. 50-55. [in Russian].

2. Saukh P. Yu. ta in. (2011) Innovaciyi u vyshhij osviti: problemy, dosvid, perspektyvy [Innovations in higher education: problems, experience, prospects]: monohrafiya. red. P. Yu. Saukh. Zhytomyr: Vyd-vo ZhDU im. I. Franka. [in Ukrainian].

3. Fathuddinova O. V. (2012) Vprovadzhennia novykh tehnolohii v protsessi pidhotovky spetsialistiv pravoznavstva [Implementation of new technologies in the process of training the law specialists]. Humanit. Visn. Zaporiz. Derzh. Inzh. Akad. 48. 35-39. [in Ukrainian].

4. Beatty K. (2015) Mobile language learning: the world in our hands. Anaheim University, USA. 17. Retrived from: www.anaheim.edu/schoolsand-institutes/graduate-school-ofeducation/diplomain-tesol/243-about/facultyand-staff/tesol-faculty/886-ken-beatty-phdken-beatty-phd (accessed 10.07.2019)

5. Brown H. D. (2007) Teaching by Principles: An Interactive Approach to Language Pedagogy. New York: Pearson Education. 3d edition.

6. Dincer A., Goksu A., Takkac A., Yazici M. (2013) Common Characteristics of an Effective English. The International Journal of Educational Researchers. 4(3). 1-8.

7. Frank V. M., Freynik S., Richardson D. L. (2014) Technologies for foreign language learning: a review of technology types and their effectiveness. Center for Advanced Study of Language, University of Maryland, College Park, MD. 1.

8. Park G.-P., Lee H.-W. (2006) The characteristics of effective English teachers as perceived by high school teachers and students in Korea. Asia Pacific Education Review 7(2). 236-248.

Ponikarovska Svitlana ${ }^{1}$, Senior Lecturer, +38 067-782-52-50, ponikarovska@gmail.com, ${ }^{1}$ Kharkov National Automobile and Highway University, 25, Yaroslava Mudrogo str., Kharkiv, 61002, Ukraine.

Нові підходи у викладанні англійської мови студентам автомобільних спеціальностей

Анотація. Нові підходи до викладання іноземної мови $\epsilon$ питанням багатьох дискусій та досліджень. Комп'ютери та телекомунікаиії трансформують вищу освіту, стають невід'ємною частиною навчального процесу.
Студенти інженерних вищих навчальних закладів, особливо майбутні автомобільні інженери, бо вони знаходяться на передовій економіки, потребують поєднання традиційних та технологічних методів вивчення мови, які забезпечать простір для успішного навчання. Застосування нових технологій повинно бути допоміжним, а не самостійним інструментом. Завдання викладача бути невід'ємною частиною проиесу, а не оператором комп'ютера. Виховання у студентів здібностей до самостійного мислення $\epsilon$ головною метою в навчанні сьогодні. Мета статті - довести, щзо сектор освіти не $е$ винятком у нашому суспільстві, щуо швидко розвивається. Характер иільової аудиторії означає, ще освітній сектор повинен адаптуватися до нових вимог, щуо означає комп'ютерну грамотність та доброзичливу атмосферу із головною метою сприяти успішному навчанню.

Ключові слова: атмосфера; спілкування; технологія; знання; навчання; інтерактивний.

Понікаровська Світлана Володимирівна ${ }^{1}$, старший викладач каф. іноземних мов, +38 067782-52-50, ponikarovska@gmail.com,

${ }^{1}$ Харківський національний автомобільнодорожній університет, 61002, Україна, м. Харків, вул. Ярослава Мудрого, 25.

Новые подходы к преподаванию английского языка студентам автомобильных специальностей Аннотация. Компьютеры и телекоммуникации трансформируют выстее образование, становятся неотъемлемой частью учебного прочесса. Студенты технических ВУЗов требуют сочетания традиционных и технологических методов изучения языка. Использование новых технологий должно быть вспомогательным, а не самостоятельным инструментом. Задача преподавателя быть неотъемлемой частью процесса, а не оператором компьютера. Воспитание $y$ студентов способностей $\kappa$ самостоятельному мышлению является главной целью в обучении сегодня. В работе доказано, что сектор образования не является исключением, он должен адаптироваться к новым требованиям, что означает компьютерную грамотность $и$ доброжелательную атмосферу для способствования успешному обучению.

Ключевые слова: атмосфера; общение; технология; знания; обучение; интерактивный.

Поникаровская Светлана Владимировна ${ }^{\mathbf{1}}$, старший преподаватель каф. иностранных языков, тел. +38 067-782-52-50, ponikarovska@gmail.com,

${ }^{1}$ Харьковский национальный автомобильнодорожный университет, 61002, Украина, г. Харьков, ул. Ярослава Мудрого, 25. 